'AINSWOR'TH, N. J. (1928), Roy. Dent. Hosp. Mag., 2, 2-15. ${ }^{8}$ AINSWORTH, N. J. (1933), Brit. Dent. F., 55, 233.

${ }^{9}$ DEAN, T. (1946), 'A.A.A.S. Dehtal Caries and Fluorine,' 5-3 r. ${ }^{10}$ BLACK, G. V., and MCKAY, F. S. (1916), Dental Cosmos, 58, 129. "McKAY, F. S. (1929), Dental Cosmos, 71, 747.

${ }^{12}$ MCCLURE, F. J. (1946), 'A.A.A.S. Dental Caries and Fluorine,' 74-92.

${ }^{13}$ MCCLURE, F. J. (1949), U.S. Pub. Health Repts., 64, 34.

${ }^{14}$ BROMEHEAD, C. N., MURRAY, M. M., et al. (1943), The Lancet, April 17, 1943, 490.

${ }^{1}$ MCCLURE, F. J. (1943), Am. 7. Disease of Children, 66, 362.

${ }^{16}$ MCCLURE, F. J., et al. (1945), 7. Industrial Hyg. and Tox., 27, I59.

${ }^{17 M C C L U R E, ~ F . ~ J ., ~ a n d ~ K I N S E R, ~ C . ~ A . ~(1944), ~ U . S . ~ P u b . ~ H e a l t h ~}$ Rep., 59, 1575.

${ }^{1}$ SMITH, F. A., et al. (1950), 7. Dent. Res., 29, 569.

${ }^{1}$ PANDI'T, C. G., et al. (1940), Indian F. Med. Res., 28, 533.

${ }^{20}$ MURRAY, M. M., and WILSON, D. C. (1948), Rrit. Dent. F., 84, 97.

${ }^{2}$ SHORT, E. M. (1944), F. Dent. Res., 23, 247.

"2:MCCLURE, F. J., and LikiNs, R. C. (1950), F. Dent. Res., 29, 315.

${ }^{23}$ MCCLURE, F. J. (1948); F. Dent. Res., 27, 287.

"IDEAN, H. T., et al. (1939), U.S. Pub. Health Repts., 54, 862.

${ }^{25}$ DEAN, H. T. (1947), Am. f. Orth. and Oral. Surg., 33, 49.

${ }^{26}$ WEAVER, R. (1944), Brit. Dent. F., 75, 29.
${ }^{27}$ WEAVER, R. (1950), Brit. Dent. F., 88, 23 I.

${ }^{28}$ WEAVER, R. (1948), Proc. Roy. Soc. Med., 41, 284.

${ }^{29}$ HODGE, H. D. (1950), F. Am. Dent. Ass., 40, 436 .

${ }^{30}$ KLEIN, H. (1947), Science, 105, 45.

${ }^{31}$ KLEIN, H. (1948), U.S. Pub. Health Rept., 63, 563.

${ }^{32}$ ARNOLD, F. A., JUN. (1946), 'A.A.A.S. I)ntal Caries and Fluorine,' 99-107.

${ }^{33}$ RUSSELL, A. L. (1949), f. Dent. Res., 28, 298.

${ }^{34}$ DEATHERAGE, C. F. (1943), $\mathcal{Y}$. Dent. Res., $22,129$.

${ }^{3}$ FORREST, J. R., PARFITT, G. J., et al., in press.

${ }^{36}$ BULl, F. A. (1950), F. Am. Dent. Ass., 41, 146.

37BULL, F. A. (1951), Ұ. Am. Dental Ass., 42, 29.

${ }^{38}$ STREAN, L. P., and BEAUDET, J. P. (1945), N. Y. State F. of Med., 45,2183 .

$3^{9}$ IRVING, J. 'T. (1949), f. Dent. Res., 28, i 7.

${ }^{\circ}$ GEROULD, C. H. (1945), F. Dent. Res., 24, 22.

${ }^{4}$ CLAPPER, W. E. (1947), Proc. Soc. Exp. Bio. and Med., 65, 333. 42DEAN, H. T., et al. (1941), U.S. Pub. Health Rept., 56, 365.

${ }^{4}$ ARNOLD, F. A., DEAN, H. T., et al., U.S. Pub. Health Repts., 57,773 .

"BOREI, H. (1945), 'Arkiv. for Kemi-Mineraloci och geoloci 20A,' N. $8,208$.

${ }^{45}$ MCCLURE, F. J. (I94I), Amer. F. Dis. Child., 62, 5 I 2.

${ }^{46}$ HODGE, H. C., and SOGNNAES, R. F. (1946), 'A.A.A.S. Dental Caries and Fluorine,' 53-7.3.

\title{
WOMEN IN MEDICINE: THE EARLY YEARS
}

\author{
By MaY Thorne, O.B.E., M.D., F.R.C.S.I., L.S.A.
}

A hundred years ago a stirring began to be felt by a few women both here and in America that they should be able to prepare themselves to enter the medical profession. Elizabeth Blackwell was the first woman in America who, about $185^{\circ}$, made up her mind to study medicine. She had no idea at that time of the difficulties that stood between her and qualification, but by dint of attending a few lectures here and there, by making use of every scrap of experience, by reading and by the help of a few physicians who sympathized with her in her ambition, she, after some years of hard struggle and disappointing work, managed to present herself for examination at the University of Geneva in the State of New York, passed and became a qualified physician.

In England a few years later Elizabeth Garrett had similar ambitions. She met with similar trying experiences, but she, too, persevered in an indomitable way. She had the friendship of some of the leading medical men, who gave her sym- pathy, though they could give her little help; but she got a little teaching and experience here and there and made the best possible use of it. After some years she learned that the Society of Apothecaries of London admitted, to their licence to practise medicine, students who held the certificate of a practical apothecary. She became apprenticed and subsequently qualified as an apothecary, and in 1865 applied for admission to present herself at the final examination. She was admitted to the examination, passed and was thus the first woman in England legally qualified to practise as a physician of medicine. The Society was apparently horrified at what it had done, and at once took steps to alter its regulations for admission to the examination, by making a rule that in future, certificates of instruction from a recognized medical school must be presented by all candidates for the final examination. This regulation prevented any other woman from presenting herself for the final examination. 
At this time (1865) Sophia Jex-Blake, who had seen something of Dr. Lucy Sewell's good work in America, made up her mind to study medicine in England and applied to the University of Cambridge, among other places, to be admitted as a medical student, but was refused by all. She then applied to the University of Edinburgh for admission to its course of medical study, but was refused on the ground that the Senate did not see its way to open its course in the interest of only one woman. This decision received much notice in the Press and was seen by Mrs. Isabel Thorne, my mother, who at once wrote to Miss Jex-Blake that she would be glad to join her in the event of her making another application and that she thought she knew two or three friends who would join them. This was done, and in the autumn of s869 five women, after passing the matriculation examination of the University, received their cards of Civis Academiae Edinensis showing them to be full students of the University. All now seemed straightforward and the five women attended the lectures for the first academic year (1869-70), though in separate classes as co-education was deemed to be inadvisable. At the end of the winter session the usual class examinations were held and in that for chemistry all the women passed, four taking honours and one, Miss Edith Pechey, took the first place. She thus became eligible for the Hope Scholarship, but this was withheld and given to the man who took the second place. The women's success was certainly to their own disadvantage, for the men students were annoyed that the women had done so well. From this time onward there was a feeling of opposition amongst certain of the men to the facilities accorded to the women students.

For the session 1870-71 women were admitted to the classes of anatomy and physiology and all went smoothly for a time. The anatomy lectures and weekly examinations were held in the College of Surgeons and on a dark November afternoon in 1870 a crowd of noisy young students assembled outside the gates of the College at the time the usual weekly class examination was to be held and effectually barred the way to the entrance. A friendly student who was in the College grounds, however, opened the gate from the inside and the women proceeded to the examination with their fellow men students, many of whom were always very friendly and helpful to them. It was suggested to the women that they should leave the College by a private door, as the crowd of noisy young students still lingered about the gate, but the women felt it would never do to be intimidated and, accompanied by several loyal members of the class armed with osteological specimens, made their way through the crowd and reached home safely. No damage was done to them personally, but much mud and many rotten eggs were thrown, which soiled their clothes. The loyal band accompanied the women to and from their anatomy classes for a week or Io days and the noisy young students, finding they could not deter the women from attending at Surgeons Hall, soon contented themselves with writing abusive anonymous letters which, though unpleasant to receive, did no harm.

Several women secured marks which qualified them for prizes during this session, but the usual presentation of prizes did not take place at the end of the winter session, as neither the President of the College of Physicians nor the President of the College of Surgeons would take the chair as usual, owing to women being amongst the prizewinners.

The question of clinical instruction now became an urgent matter. All medical students at Edinburgh do their clinical work in the wards of the Royal Infirmary. It was known that the Lord Provost, at the annual meeting in January $187 \mathrm{I}$, would propose six members favourable to the admission of women as students, but, the resolution being lost, all chance of the women obtaining hospital teaching was at an end for at least a year. As the agitation continued to increase and the struggles of the women to obtain a qualifying course in the University, which had admitted them as full students, became more widely known, man people became interested in their efforts and an influential committee of over 500 members was quickly formed. From that time the little band of women were no longer an isolated group struggling for themselves, but the pioneers of an important movement strengthened by friends willing and able to help with money and wise counsel.

The five original women students were now eligible for the first professional examination. Three of them applied for admission, paid their fees and had received their tickets when, ro days before the date of the examination, they received official notice that they would not be admitted to it. The newly formed committee at once obtained legal opinion and on the strength of this the three students appealed to the Senatus of the University; the day before the examination the order was withdrawn. All the students passed, taking honours in more than one subject.

The women were now refused their third-year matriculation tickets, but the Senatus again overruled the action of the Medical Faculty and declared that as long as the regulations for the admission of women remained on the calendar they must be carried out. In January 1872 the Infirmary question came up again. This time it was decided that the clinical advantages of the Infirmary should 
be available to all medical students under such regulations as the managers might appoint. These regulations were that the women's attendances should be separate from the men's and that they only went to the wards to which they were invited. They were, therefore, able to begin a course of qualifying hospital instruction, though of a very limited character. Thanks to the kindness of several medical men, the students were also admitted to the practice of the Royal Dispensary, to Chalmer's Hospital and to the Poor House Infirmary. Litigation on many questions arose and had to be fought and the validity of the regulations passed in 1869 was questioned. All the statutory authorities of the University had authorized them, but this did not prevent the question of ultra vires being raised. The Lord Advocate for Scotland and Sheriff Fraser gave their opinion that the regulations were in order and an action of declarator was brought against the Senatus praying to have it declared that the Senatus was bound to enable the women to complete their education and to present themselives for the medical degree. The Lord Ordinary, Lord Gifford, before whom the action was first picaded, gave it as his judgment that the women were entitled to be admitted to the study of medicine in the University, subject to certain conditions, but the Senatus decided to appeal against this judgment. After a delay of about a year the appeal was brought before the 12 judges of the Inner House, when by a majority of two votes it was decided that legally the University had exceeded its powers in 1869 . No more could therefore be done in Edinburgh and the great object of the women to obtain admission to examinations that, if passed, would entitle them to be placed on the Medical Register seemed as far off as ever.

There was an examination in midwifery at the Royal College of Surgeons, England, that, if passed, would entitle them to be placed on the Medical Register. Two of the original five women applied for admission, but the examiners resigned at this time and the College did not appoint others to take their place. There were thus, in 1876 , still only two women on the Medical Register and apparently no hope of others being admitted to it.

Miss Jex-Blake, Mrs. Thorne and Miss Pechey decided to see what could be done in London and, with the help of a provisional committee on which sat Professor Huxley, F.R.S., Dr. Burdon Sanderson, Mr. Critchett and others, it was decided to form a complete course of non-clinical study given by already recognized teachers at London medical schools in the hope that one or other of the 19 medical boards would accept their certificates from women as well as from men medical students.
Classes were opened at the London School of Medicine for Women in October 1874 with 14 students, 12 of whom had been students in Edinburgh. In 1875 the Provisional Council handed over the institution to a body of governors elected by the subscribers and themselves, who made applications to the London general hospitals for admission for clinical instruction for their students, but without success. All the examining boards refused to accept the certificates of attendance at the School in spite of the lecturers being recognized teachers.

The Rt. Hon. W. Cowper-Temple, M.P., who had carried through the Medical Act of $185^{8}$, declared that the Medical Act was not intended to confine the practice of medicine to men, for in I 858 the question of women entering the profession had not arisen. In 1876 he brought in a Bill to remove doubts as to the powers of the universities of Scotland to grant degrees to women, but its second reading was opposed by the University of Edinburgh and was thrown out:

In 1876 the Rt. Hon. Russell Gurney, M.P., Recorder of London, introduced a short permissive Bill giving British examining boards power to admit women to their examinations. The Bill became law, but for some years no board acted upon it. When the three years' curriculum of non-clinical studies was completed in 1877 the 34 women who had taken it seemed as far off as ever from qualification. Just when the outlook seemed most gloomy, however, the King's and Queen's College of Physicians (now the Royal College of Physicians of Ireland) decided to admit a few women who had studied in Edinburgh, and who now held degrees from the Universities of Berne and Zurich, to their final examination. They all passed and received the licence of the College, which entitled them to be registered by the General Medical Council of Great Britain and Ireland and to enter upon the legal practice of medicine. Two difficulties were thus overcome, for the non-clinical studies were now recognized and a qualifying examination was open to women, but no clinical instruction was available. After considerable delay the Royal Free Hospital, which then had no students, bound itself on certain conditions to admit students of the School to its wards for clinical instruction and experience. So at long last any woman who desired to qualify as a medical practitioner could take her education at the London School of Medicine for Women and the Royal Free Hospital and could present herself for examination at the King's and Queen's College of Physicians, Ireland, and, if successful, receive the licence of the College. Laus Deo. 